\title{
Öğretmen Adaylarının Farklı Bilgi Uçurma (Whistle- blowing) Tercihlerinde Belirleyici Olan Kültürel Değerler *
}

\author{
Asiye TOKER GÖKÇE ${ }^{* *} \quad$ Ebru OĞUZ ${ }^{* * *}$
}

Öz

Bu araştırma, öğretmen adaylarının farklı bilgi uçurma tercihlerinde belirleyici olan kültürel değerleri irdelemektedir. Bu bağlamda, öncelikle öğretmen adaylarının hangi etik/yasa dışı durum hakkında bilgi uçurabilecekleri ile olası bilgi uçurma tercihleri incelenmiştir. Ardından katılımcıların okullarda sahip oldukları kültürel değerler ile olası bilgi uçurma tercihleri arasında bir ilişki olup olmadığı incelenmiştir. Araştırma tarama modeline göre desenlenmiştir. Araştırma grubunu, 2013-2014 öğretim yılında, İstanbul ve Ankara'da iki farklı üniversitede Pedagojik Formasyon Sertifika Programı'na devam eden 289 öğretmen adayı oluşturmaktadır. Araştırmaya katılan öğretmen adaylarının \%73'ü kadın, \% 27'si erkektir. Öğretmen adayları cinsel taciz, rüşvet ve hırsızlık olaylarında bilgi uçurabileceklerini belirtmiştir. Araştırma sonucunda katılımcılar kimliğini açıklayarak, dışa resmi kanalarla bilgi uçurabilecekleri ortaya çıkmıştır. Öğretmen adaylarının bireyci kültürel değeri toplulukçu değere göre daha yüksektir. Son olarak kültürel değerler ile bilgi uçurma tercihi arasında pozitif yönde anlamlı ilişkinin olduğu belirlenmiştir. Okullarda verilen eğitimin kültürel değerlerin oluşmasında etkili olduğu bilinmektedir. Dolayısı ile halihazırda görev yapan öğretmenlerin kültürel değerleri ile çalışılan bilgi uçurma konusunun öğretmen adayları ile de çalışılması gereği doğmaktadır.

Anahtar Kelimeler: Bilgi uçurma, bireycilik, kültürel değer, öğretmen adayı, toplulukçuluk.

\section{Prospective Teachers' Cultural Orientations as Determinants of Preference for Different Modes of Whistle-Blowing}

\begin{abstract}
This paper examines whistle-blowing intentions of prospective teachers. Therefore, the kinds of ethical / illegal cases the prospective teachers would blow the whistle, and their choices of whistle blowing were examined at first. Then, possible relationship between the participants' cultural values and choices of whistle blowing were examined. The research was figured as survey model. The research group involved 289 prospective teachers who participated a teacher certification program at İstanbul and Ankara in 2013-2014 academic year. $73 \%$ of the participants were female and $27 \%$ were male. The instruments were constructed by the literature. The prospective teachers revealed that they would blow the whistle when they would observe sexual abuse, bribery, and theft. The results revealed that the participants would prefer identified whistle blowing by using formal channels to the external. The prospective teachers' individualism cultural
\end{abstract}

\footnotetext{
* Bu çalışmanın bir kısmı 9. Uluslararası Balkan Eğitim ve Bilim Kongresi'nde sunulmuştur.

** Doç. Dr. Kocaeli Üniversitesi, Eğitim Fakültesi,Eğitim Bilimleri Bölümü, Kocaeli, asi.gokce@kocaeli.edu.tr

*** Doç. Dr. Mimar Sinan Güzel Sanatlar Üniversitesi, Fen Edebiyat Fakültesi, Eğitim Bilimleri Bölümü, İstanbul ebru.oguz@msgsu.edu.tr
} 
value is higher than the other one. Finally, there was positive significant relationship between the cultural value and the choice of whistle blowing. The fact that education at schools forms cultural value is well known. Therefore, it is possible that all reforms at the education system would differentiate prospective teachers' cultural values. Thus, the need of studying whistle blowing among the prospective teachers as well as the teachers is arisen.

Keywords: Whistle blowing, individualism, cultural value, prospective teacher, collectivism.

\section{GİRIŞ}

İşgörenler örgüt içinde görevlerini yerine getirirken çeşitli istenmeyen davranışları da gösterirler. Örneğin Henle ve ark. (2005) işgörenlerin yarıdan çoğunun örgütlerde çeşitli suçlar işlediğini; en azından örgüte ait bir eşyayı çaldı̆̆ $1-$ nı ortaya koymuşlardır. Örgütlerde işgörenler tarafından gerçekleştirilen çeşitli suçlar örgüte zarar verebileceği gibi örgütün dışındaki paydaşlara da zarar verici olabilir. Diğer yandan örgüt yönetimi, kamuya veya paydaşlarına zarar verici sonuçları olacak eylemleri, kasıtlı olarak işgörenine emredebilir. Miceli ve Near (2005) böyle durumlarda ortaya çıkabilecek zararı önlemede en etkili unsurun yine işgören olduğunu belirtirler. Bu yazarlara göre işgörenler yönetim tarafından kendilerine emredilen veya örgüt içinde tanık oldukları, kamuya veya üçüncü kişilere zarar verici sonuçları olan durumları, olaya müdahale yetkisi olan birilerine bildirirse, söz konusu zararlı sonuçların önüne geçilebilir. Örgütlerde ortaya çıkan ve üçüncü kişilere zararlı sonuçları olacak eylemleri, bu kişilerin zarar görmesini engellemek, kamu yararını gözetmek amacı ile yetkililere bildirmek alan yazında bilgi uçurma (whistle blowing) adı ile anılmaktadır. Bilgi uçurma basit bir 'ispiyonlama' değil, 'prososyal' bir davranıştır. Dolayısı ile Avustralya, Japonya, Güney Kore, Yeni Zelanda, Büyük Britanya ve ABD gibi birçok ülkede yasal olarak desteklenen ve güvence altına alınan (Asian Institute of Management, 2006; Institute of Public Administration, n.d) bir davranıştır.

Türkiye'de eğitimciler üzerine yapılan bir araştırmada (Toker Gökçe, 2013a) öğretmenlerin okullarda yönetmeliklerin uygulanmaması sonucu okulun kaynaklarının boşa harcanması; kişisel çıkar için makamın kullanılması ve gereksiz veya eksik yarar veya hizmet alınarak okulun parasının boşa harcanması gibi eylemler ile karşılaştıkları belirlenmiştir. Diğer yandan, Toker-Gökçe ve Oğuz (2014) ile TokerGökçe ve Alataş (2014) çalışmalarında eğitimcilerin cinsel taciz, rüşvet, okulun ödeneğinden para çalınması veya okula ait bir eşyanın çalınması durumlarında bilgi uçurmayı tercih edeceklerini ortaya koymuşlardır. Bu çalışma da öğretmenlerin farklı bilgi uçurma tercihlerinde belirleyici olan kültürel değer yönelimlerini belirlemeyi amaçlamaktadır. Bu çalışma öncelikle eğitimcilere okullarda karşılaştıkları, kamuya veya üçüncü şahıslara zararı olabilecek her tür eylemi durdurmak adına seçenekleri olduğunu göstermesi bakımından önemlidir. Diğer yandan, çalışmanın sonuçlarının eğitim yöneticilerine okullarda yaşanan her tür yolsuzluk ve etik dışı eylem ile mücadele etmede yararlı olacağı düşünülmektedir.

\subsection{Teorik Bilgi}

\subsubsection{Bilgi uçurma}

Bir örgütte yönetimin bilgisi altında gerçekleşen, üçüncü şahıslara zararlı sonuçları olacak her tür yasa dışı veya etik dışı eylemden haberi olan işgörenlerin, bu eylemi durdurmak için müdahale yetkisi olan birilerine bildirmesine bilgi uçurma denir (Miceli ve Near, 1985). Bilgiyi uçuran kişi örgütün hali hazırda görev yapan iş göreni olabileceği gibi, örgütte daha öne çalışmış biri de olabilir. Park ve ark. (2008) farklı bilgi uçurma biçimleri ortaya koymuşlardır. Bunlar: resmi veya resmi olmayan biçimde; 
içe veya dışa; kimliğini açıklayarak veya kimliğini saklayarak (anonim) biçiminde sıralanmaktadır. Resmi bilgi uçurma, örgütün belirlediği kurallar çerçevesinde uyulması gereken süreçler takip edilerek bilgi uçurma biçimidir. Söz konusu süreçlere uyulmadan, kişinin haberdar olduğu bilgiyi güvendiği birine haber vermesine resmi olmayan bilgi uçurma denir. İşörenin haberdar olduğu durumu örgütün içindeki yetkili birilerine rapor etmesine 'içe bilgi uçurma', medya, meclis veya meslek odaları gibi örgüt dışındaki birilerine bildirmesine 'dışa bilgi uçurma' denir. Bilgiyi uçuran işgören gerçek adını kullanır veya kimliğini açıklayıcı bilgi verirse 'kimliği belirli bilgi uçurma'; takma ad kullanır veya kimliğini gizlerse 'anonim bilgi uçurma' adı verilir (Miceli ve Near, 1994; Vinten, 1996; Park ve ark. 2008).

Bilgi uçurma çeşitli yazarlarca (Near ve Miceli, 1985) prososyal davranış olarak kabul edilir. Dolayısı ile bilgi uçurma ispiyonculuk değil, örgüt içinde sosyal yarar sağlayıcı bir davranıştır. Örgütlerde işgörenleri tanık oldukları yasal veya etik olmayan eylemler hakkında harekete geçmeye iten veya buna engel olan çeşitli faktörler vardır. Bunlar; kişisel, örgütsel ve durumsal faktörlerdir. Kişinin etik farkındalık düzeyi, sahip olduğu değerleri veya cinsiyeti kişisel faktörler arasında yer alır. Örgütün yapısı, kültürü, yönetimin liderlik tarzı örgütsel faktörlerdendir. Haberdar olunan etik veya yasa dişı eylemin türü de durumsal faktörler arasında sayılabilir (Miceli ve ark., 1991; Miceli ve Near 1994).

İşgörenlerin kendilerine yapılması emredilen veya haberdar oldukları etik veya yasa dışı eylem hakkında bilgi uçurabilmeleri için öncelikle söz konusu eylemin yasa dışı veya etik dışı olup olmadığının farkında olması gerekir. Dolayısı ile işgörenin öncelikle söz konusu eylemi etik açıdan tanımlaması gerekir. İkinci aşamada işgörenin etik yönden yargıya varma- s1 gerekir. Üçüncü aşamada söz konusu eylem hakkında bir şeyler yapılması gerektiğine inanması gerekir. Son olarak da harekete geçilir (Woiceshyn, 2011).İ̧̧görenin bilgi uçurmaya karar vermesinde gerçekleştirdiği bu süreçlerde yukarıda sözü edilen faktörlerin etkisi vardır. Kişilerin sahip oldukları kültürel değerleri de bu faktörler arasında yer alır.

\subsubsection{Bilgi Uçurma ve Kültürel Değer Yöneli- mi}

Kültür üzerine çalışmaları ile bilinen Hofstede (1983) 40 ülkeyi dört kültürel boyutta incelemiştir. Bunlar bireycilik ve toplulukçuluk, güç mesafesi, belirsizlikle baş edebilme ve dişil-eril değer boyutlarıdır. Bununla birlikte, kültür çalışmaları yapan araştırmacılar genelde toplumların bireyci (individual) veya toplulukçu (collectivist) olma özelliğini araştırmışlardır. Dolayısıyla bireycilik veya toplulukçuluk genelde ulusal özellik olarak ifade edilir. Bunun sonucunda ülkeler genelde az veya çok bireyci veya toplulukçu biçiminde anılır (Hofstede, 1980). Bireycilik kişilerin bir grubun üyesi olmayı tercih etmeyip ayrı hareket etme derecesidir. Bireyci toplumlarda kişi öncelikle kendi amaçlarının peşinden koşar. Toplulukçu kültürlerde ise kişiler kendilerini bağımsız bir birey olarak değil, bir grubun üyesi olarak görürler. Dolayısı ile üyesi oldukları gruba bağlllık gösterdikleri sürece grubun kendilerini ve kişisel çıkarlarını koruyacağını düşünürler (Taras ve ark. 2012).

Hofstede (1983) kurumların ve yasaların işleyiş biçimleri ile yıllarca belirli kurallar içinde yaşayan bireylerin sonunda ortak bakış açısına sahip olabileceğini belirtir. Buna dayanarak kültürü kolektif bir zihin oluşturan bir programlama biçiminde tanımlar. Hofstede aynı bölgede veya devlette yaşayan bireylerin alg1lamada veya davranışlarında benzer olacağını, farklı bölge veya devlette yaşayan bireylerin ise de farklı özellikler göstereceğini vurgular. Buna 
göre farklı kültürlerde yaşayan bireylerin bilgi uçurma eğilimlerinin de farklı olabileceği düşünülebilir. Dolayısı ile birinin sahip olduğu kültürel değerleri bilmemiz, onun bilgi uçurma eğilimini anlamamıza yardımcı olacaktır. Nitekim Miceli ve ark. (2009) kültürel özeliklerin etik dışı bir olaya tanık olan kişinin olaya müdahale edilmesi hakkında karar vermesini etkilediğini iddia etmektedir. Kültürün bilgi uçurma eğilimine etkisini araştıran bazı çalışmalar da yapılmıştır. Söz konusu çalışmalar bireyci veya toplulukçu kültürel özellikler temel alınarak gerçekleştirilmiştir. Örneğin Keenan (2002) Amerikalı ve Hintli yöneticilerin bilgi uçurma olasılığını karşılaştırmıştır. Tavakali ve ark. (2003) ABD'li ve Hirvat yöneticiler arasında bilgi uçurma eğiliminde farklılıklar bulmuştur. Park ve ark. (2008) Güney Koreli, Türk ve Büyük Britanyalı öğrencilerin bilgi uçurma eğilimlerini karşılaştırmıştır. Bu çalışmada öğrenciler arasında bilgi uçurmaya yönelimde çok büyük farklılık çıkmamıştır. Nayir ve Herzig (2012) Türk yöneticilerinin bilgi uçurma olasılığını irdelediği araştırmada bireyciliğin dışa ve anonim bilgi uçurma ile ilişkisini ortaya koymuşlardır. Toker Gökçe (2013b) Türkiye'de öğretmenlerin kültürel değerlerinin bilgi uçurmaya etkisini araştırmıştır. Söz konusu araştırmada katılımcılarda bireycilik kültürel değeri daha yüksek çıkmıştır. Bununla birlikte hem bireyci hem de kültürel değerlerin bilgi uçurma biçimleri ile ilişkisi olduğu ortaya çımıştır. Son olarak Toker-Gökçe ve Oğuz (2014) öğretmenlerin kültürel yönelimleri ile bilgi uçurma tercihleri arasındaki ilişkiyi irdelemiştir. Söz konusu çalışmada katılımcılarda toplulukçuluk kültürel değerin bireycilik değerinden daha yüksek olduğu görülmüştür. Ayrıca kültürel değerlerin bilgi uçurma tercihleri ile ilişkili olduğu de belirlenmiştir.

Hofstede (1983) kültürü kolektif mental program biçiminde tanımlarken, eğitim kurumlarının ortak kültür inşa etmedeki rolüne de vurgu yapar. Ona göre aynı eğitimi alan bireyler benzer kültür değerlerine de sahip olabilir. Buna dayanarak insanların aldıkları eğitim sayesinde benzer biçimde algılamaya ve davranmaya koşullandığı söylenebilir. Türkiye'de eğitim sisteminde Cumhuriyetin kuruluşundan günümüze birçok reform yapılmıştır. Bu durum öğretmen yetiştirme sistemi için de geçerlidir.1982 yılında Millî Eğitim Bakanlığı'na bağlı olan öğretmen yetiştiren yükseköğretim kurumları üniversitelere bağlanmıştır. Bu reform sırasında öğretmen yetiştiren programların içeriği de değiştirilmiştir. Yapılan reformlara 1997'de yenileri eklenmişse de öğretmen yetiştirmede yeniden yapılanmaya 2007 yılında da gidilmiştir (Kavak ve ark. 2007). Türkiye'de öğretmen yetiştirme sisteminde yapılan her bir değişim bir önceki paradigmayı değiştirmeyi amaçlamıştır. Dolayısı ile her bir değişim farklı paradigmaya sahip öğretmenler ortaya çıarmıştır. Bu bağlamda her bir dönem öğretmenlerin veya öğretmen adaylarının kültürel eğilimlerinin bir önceki dönemden farklılık gösterebileceği düşünülmektedir. $\mathrm{Bu}$ bağlamda Toker-Gökçe ve Oğuz (2014) tarafından gerçekleştirilen ve öğretmenlerin kültürel yönelimleri ile bilgi uçurma tercihleri arasındaki ilişkiyi irdeleyen araştırmanın, öğretmen adayları için de yapılmasının gerekli olduğu düşünülmektedir. Bu çalışmanın amacı öğretmen adaylarının olası bilgi uçurma tercihleri ile kültürel değerleri arasındaki ilişkiyi belirlemektir. Araştırma kapsamında aşağıdaki sorulara yanıt aranmıştır:

Öğretmen adayları okullarda hangi tür istenmeyen davranışa/yolsuzluğa tanık olduklarında bilgi uçurulması gerektiğini düşünmektedir?

Öğretmen adayları olası tanık oldukları eylemler hakkında hangi tür bilgi uçurmayı tercih etmektedir? 
Öğretmen adaylarının bilgi uçurma tercihleri cinsiyete ve mezun olunan bölüme göre farkl1laşmakta mıdır?

Öğretmen adaylarının sahip oldukları kültürel değerleri cinsiyete ve mezun olunan bölüme göre farklılaşmakta mıdır?

Öğretmen adaylarının olası bilgi uçurma tercihlerinde kültürel değerlerine göre farklılaşma var midir?

Öğretmen adaylarının olası bilgi uçurma tercihleri ile kültürel değerleri arasında bir ilişki var midir?

\section{YÖNTEM}

Tarama modelinde yapılan bu araştırma, öğretmen adaylarının bilgi uçurma türlerini, hangi durumlarda bilgi uçurdukları ve öğretmen adaylarının sahip oldukları kültürel değerleri incelemeye yönelik betimsel bir çalışmadir.

\subsection{Araştırma Grubu}

Tablo 1. Katılımcıların Cinsiyetlerine, Yaşlarına ve Mezun Oldukları Bölüme Göre Dağılımları

\begin{tabular}{lll}
\hline Cinsiyet & $\mathbf{N}$ & $\mathbf{\%}$ \\
\hline Kadın & 210 & 72,7 \\
Erkek & 79 & 27,3 \\
Yaş & $\mathbf{N}$ & $\%$ \\
$20-25$ yaş & 127 & 43,9 \\
$26-30$ yaş & 117 & 40,5 \\
30 yaş ve yukarısı & 45 & 15,6 \\
Bölüm & $\mathbf{N}$ & $\%$ \\
Dil & 124 & 42,9 \\
Sanat ve Tasarım & 77 & 26,6 \\
Felsefe & 12 & 4,2 \\
Sosyoloji & 5 & 1,7 \\
Tarih & 27 & 9,3 \\
Fizik & 20 & 6,9 \\
Ziraat Mühendisliği & 6 & 2,1 \\
Illahiyat & 17 & 5,9 \\
\hline Toplam & $\mathbf{2 8 9}$ & \\
\hline 3.2.Veri Toplama Araçları & & Türde Bilgi Uçurma Tutumları Anketi' öğret- \\
Araştırmada üç farklı veri toplama aracı kulla- & men adaylarına uyarlanarak kullanılmıştır. Bu \\
nılmıştır. Araştırmaya katılanların demografik & & \\
Özelliklerini belirlendikten sonra, birinci bölü- & kategorilerine göre oluşturmuş oldukları 'Farklı \\
\hline
\end{tabular}

Araştırma grubunu, 2013-2014 öğretim yılında, İstanbul ve Ankara'da iki farklı üniversitede Pedagojik Formasyon Sertifika Programı'na devam eden 289 adet, bir lisans programindan mezun olmuş, öğretmen adayı oluşturmaktadır. Araştırmaya katılan öğretmen adaylarının 210 'u kadın (\% 72,7) ve 79'u erkektir (\% 27,3). Öğretmen adaylarının yaş aralığı; 20-25 yaş $(n=127, \% 43,9)$; 26-30 yaş $(n=117, \% 40,5)$ ve 31 yaş ve üzeridir $(n=15, \% 15,6)$. Öğretmen adaylarının çok farklı üniversite ve bölümden mezun oldukları görülmektedir. Öğretmen adaylarının mezun oldukları bölüme göre dağılımları şöyledir: Dil bölümünden mezun olanlar ( $n=124, \% 42,9)$; Sanat ve Tasarım bölümlerinden mezun olanlar (n=77, \%26,6); Felsefe bölümünden mezun olanlar ( $\mathrm{n}=12, \% 4,2)$; Sosyoloji bölümünden mezun olanlar $(n=4, \% 1,7)$, Tarih bölümünden mezun olanlar ( $n=27, \% 9,3)$; Fizik bölümünden mezun olanlar $(n=20, \% 6,9)$; Ziraat Mühendisliği bölümünden mezun olanlar $(n=6$, $\%$ 2,1) ve son olarak İlahiyat bölümünden mezun olanlar $(\mathrm{n}=17, \% 5,9)$. 
anket, altı tür bilgi uçurma biçimini (içe (3 madde), dişa (2 madde), kimliğini açıklayarak (2 madde) ve kimliğini saklayarak (2 madde), resmi yolla ( 2 madde) ve resmi olmayan yollarla (2 madde)) sorgulayan toplam 13 maddeden oluşmaktadır. Anket 5'li Likert biçiminde düzenlenmiştir. Anketin boyutlarından bir toplam puan elde edilmiştir. Bu sonuca göre hangi tür bilgi uçurma biçimlerinin tercih edileceği belirlenmiştir.

Veri toplama aracının ikinci bölümünde araştırmacılar tarafından alan yazından (Miceli ve Near, 1988; Near ve ark. 2004) yararlanarak oluşturulan bir 'yasal/etik olmayan eylemler listesi' bulunmaktadır. Bu listede toplam 15 madde bulunmaktadır. Öğretmenlerden bu eylemlerden hangisine/hangilerine tanık olunduğunda bilgi uçurulması gerektiğini düşünüyorsa işaretlemeleri $(1=$ evet, $0=$ hayır $)$ istenmiştir.

Veri toplama aracının üçüncü bölümünde öğretmenlerin sahip oldukları kültürel değerleri ortaya koymak amaciyla 'Kültürel değerler ölçeği' kullanılmıştır. Bu ölçek Chew (1996; Akt: Taras, 2010) tarafından Hofstede'in (1980) çalışması temel alınarak hazırlanmıştır (Taras,
2010).Bu ölçek 15 maddeden oluşmaktadır. Yedi madde bireycilik, sekiz madde toplulukçuluk ile ilgilidir. Uygulanan ölçeğin güvenilirlik katsayısı (Cronbach Alfa) 0,808 olarak bulunmuştur.

\subsection{Verilerin Analizi}

Verilerin analizinde betimsel istatistikler, $\mathrm{t}$ testi, Kruskal Wallis $\mathrm{H}$ testi ve farkın kaynağını ortaya koymak için Mann Whitney U testi kullanılmıştır. Öğretmen adaylarının olası bilgi uçurma tercihleriyle kültürel değerleri arasındaki ilişkiyi ortaya koymak için Pearson korelasyon analizi yapılmışıır.

\section{BULGULAR}

Bu bölümde öğretmen adaylarının tercih ettikleri bilgi uçurma türleri, hangi durumlarda bilgi uçurmayı tercih ettikleri ve sahip oldukları kültürel değerlere ilişkin görüşlerine yer verilmiştir.

\section{1.Öğretmen adaylarının bilgi uçurulması gerektiğini düşündükleri etik dışı eylemlere ilişkin bulgular}

Öğretmen adaylarının bilgi uçurmayı düşündükleri yanlış ya da etik dışı eylemler Tablo 2'de yer almaktadır.

Tablo 2. Öğretmen Adaylarının Çalıştıkları Okullarda Tanık Oldukları Yanlış Eylemler

\begin{tabular}{lll}
\hline & Eylemler & F \\
\hline 1. & Cinsel taciz (öğrencilere) vapılması & 276 \\
2. & Cinsel taciz (öğretmenlere ve diğer iş görenlere) yapılması & 274 \\
3. & Rüşvet alınması & 266 \\
4. & Okulun ödeneğinden para çalınması & 264 \\
5. & Okula ait pahalı olabilecek (bilgisayar, duvar delme aleti gibi) bir/birkaç eşyanın çalınması & 248 \\
6. & Kişisel çıkar için makamın kullanılması & 241 \\
& Kamunun sağlığını /güvenliğini tehlikeye sokacak bir uygulamaya / duruma göz yumul- & 240 \\
7. & ması & 230 \\
8. & Kanunların veya yönetmeliklerin ciddi biçimde ihlal edilmesi & 220 \\
9. & Yönetmeliklerin uygulanmasında kişilere / gruplara ayrımcılık yapılması & 204 \\
10. & Bir müteahhit, danışman veya tedarikçiye, hak etmediği halde, yarar sağlanması & 202 \\
11. & Okulun parasını boşa harcayacak biçimde, kişilerden yarar veya hizmet alınması & 195 \\
12. & Komisyon alınması
\end{tabular}


13. Kötü yönetilen bir program ile okulun kaynaklarının boşa harcanması

14. Gereksiz veya eksik yarar veya hizmet alınarak okulun parasının boşa harcanması

Tablo 2 incelendiğinde öğretmen adaylarının en çok bilgi uçuracakları yasa ya da etik dışı davranışların; okulda öğrencilere ve öğretmenlere ya da diğer işgörenlere cinsel tacizde bulunulması, rüşvet alınması, okulun ödeneğinden para çalınması, okula ait eşyaların çalınması, kişisel çıkar için makamın kullanılması ve kamu sağlığını tehlikeye sokacak bir uygulamanın yapılması biçiminde olduğu görülmektedir.

Tablo 3. Öğretmen Adaylarının Tercih Ettikleri Bilgi Uçurma Türleri

\begin{tabular}{|c|c|c|c|c|}
\hline & & $\mathrm{N}$ & $X$ & Ss \\
\hline İçe & $\begin{array}{l}\text { Yolsuzluğu okulda uygun gördüğüm diğer öğretmenlere } \\
\text { vb. bildiririm. } \\
\text { Okulda yolsuzluğu yapan kişiden daha yetkili kişilere } \\
\text { bildiririm. }\end{array}$ & 289 & 8,46 & 1,887 \\
\hline Dişa & $\begin{array}{l}\text { Yolsuzluğu, MEB'den yetkili kişilere bildiririm. } \\
\text { Yolsuzluğu diğer okullarda çalışan öğretmenlere / müdü- } \\
\text { re bildiririm. } \\
\text { Yolsuzluğu halka / velilere bildiririm. }\end{array}$ & 289 & 9,45 & 2,85 \\
\hline $\begin{array}{l}\text { Kimliğini açık- } \\
\text { layarak }\end{array}$ & $\begin{array}{l}\text { Yolsuzluğu gerçek adımı kullanarak bildiririm. } \\
\text { Yolsuzluğu hakkımda ayrıntılı bilgi vererek bildiririm. }\end{array}$ & 289 & 6,71 & 2,37 \\
\hline $\begin{array}{l}\text { Kimliğini sak- } \\
\text { layarak }\end{array}$ & $\begin{array}{l}\text { Yolsuzluğu, takma isim kullanarak bildiririm. } \\
\text { Yolsuzluğu, ihbar ederim, ancak hakkımda hiç bilgi ver- } \\
\text { mem. }\end{array}$ & 289 & 5,01 & 2,36 \\
\hline Resmi & $\begin{array}{l}\text { Yolsuzluğu ihbar etmek için resmi kanalları kullanırım. } \\
\text { Yolsuzluğu ihbar ederken Milli Eğitimdeki silsileyi izle- } \\
\text { rim. }\end{array}$ & 289 & 7,83 & 1,908 \\
\hline Resmi olmayan & $\begin{array}{l}\text { Yolsuzluğu, müdahale edebilecek bir yakınıma sözlü } \\
\text { olarak anlatırım. } \\
\text { Yolsuzluğu düzeltmekle görevli olduğuna inandığım bir } \\
\text { yetkiliye, durumu sözlü olarak bildiririm. }\end{array}$ & 289 & 7,26 & 2,074 \\
\hline
\end{tabular}

Tablo 3'e göre öğretmen adayları; kurum içinden ziyade kurum dışına bilgi uçurmayı ve bunu yaparken de daha çok resmi kanalları kullanmayı tercih edeceğini belirtmektedir. Katılımcılar bilgi uçururken kimliklerini sak-
Araştırmanın bu bulgusu Toker-Gökçe ve Oğuz'un (2014) bulguları ile tutarlılık göstermektedir.

\section{2.Öğretmen adaylarının tercih ettikleri bilgi uçurma türlerine yönelik bulgular}

Öğretmen adaylarının tercih ettikleri bilgi uçurma türleri Tablo 3'te yer almaktadır. 
mektedir. Söz konusu araştırmada öğretmenler dışa, kimliğini saklayarak ve daha çok resmi olmayan yollardan bilgi uçurduklarını belirtmiştir.

\section{3.Öğretmenlerin kültürel değerlerine ilişkin bulgular}

Öğretmenlerin kültürel değerlerine ilişkin bilgiler Tablo 4'te yer almaktadır.

Tablo 4. Öğretmen Adaylarının Kültürel Değerlerine İlişkin Betimsel İstatistikler

\begin{tabular}{cccc}
\hline & $\mathrm{N}$ & $\mathrm{X}$ & Ss \\
\hline Bireycilik & 289 & 8,21 & 1,31 \\
Toplulukçuluk & 289 & 6,30 & 1,76 \\
\hline
\end{tabular}

Tablo 4'e göre öğretmen adaylarının daha çok bireyci kültürel düzeyine sahip olduğu görülmektedir. Araştırmanın bu bulgusu TokerGökçe ve Oğuz'un (2014) bulguları ile benzerlik göstermemektedir. Araştırmanın bu bulgusu öğretmenlerin toplulukçu kültürel değerleri bireyci değerden daha yüksek çıkmıştır. Diğer yandan bu bulgu Toker Gökçe'nin (2013b)bulguları ile tutarlıdır. Söz konusu araş- tırmada da öğretmenlerin bireyci kültürel değerleri toplulukçu değerden yüksek çıkmıştır.

4.4.Bilgi uçurma biçimi tercihinin ve kültürel değerlerin cinsiyete göre farklılaşma durumu

Cinsiyet faktörünün katılımcıların bilgi uçurma biçimi tercihlerinde ve kültürel değerlerinde fark yaratıp yaratmadığına t-testi ile bakılmıştır. Analiz sonuçları Tablo 5 'te yer almaktadır.

Tablo 5. Bilgi Uçurma Tercihi ve Kültürel Değerlerin Cinsiyete Göre Farkı T-testi Sonuçları

\begin{tabular}{|c|c|c|c|c|c|c|c|}
\hline & & $\mathrm{n}$ & $\bar{X}$ & $\mathrm{~S}$ & $\mathrm{Sd}$ & $\mathrm{t}$ & $\mathrm{P}$ \\
\hline \multirow[t]{2}{*}{ İçe } & Kadın & 207 & 8,52 & 1,77 & 287 & 883 & ,378 \\
\hline & Erkek & 79 & 8,30 & 2,15 & & & \\
\hline \multirow[t]{2}{*}{ Dişa } & Kadın & 210 & 9,43 & 2,81 & 287 & 181 &, 857 \\
\hline & Erkek & 79 & 9,50 & 2,96 & & & \\
\hline Kimliğini açı- & Kadın & 210 & 6,65 & 2,32 & 284 & 744 & 457 \\
\hline layarak & Erkek & 79 & 6,88 & 2,50 & & & \\
\hline Kimliğini sak- & Kadın & 210 & 5,03 & 2,32 & 287 & 268 & ,789 \\
\hline layarak & Erkek & 79 & 4,94 & 2,49 & & & \\
\hline \multirow[t]{2}{*}{ Resmi } & Kadın & 210 & 7,79 & 1,85 & 287 & ,511 & 610 \\
\hline & Erkek & 79 & 7,92 & 2,04 & & & \\
\hline \multirow[t]{2}{*}{ Resmi olmayan } & Kadın & 210 & 7,34 & 2,03 & 287 & 1,131 & 259 \\
\hline & Erkek & 79 & 7,03 & 2,18 & & & \\
\hline \multirow[t]{2}{*}{ Bireyci } & Kadın & 210 & 8,29 & 1,28 & 286 & 1,619 & 106 \\
\hline & Erkek & 79 & 8,01 & 1,40 & & & \\
\hline \multirow[t]{2}{*}{ Toplumcu } & Kadın & 210 & 6,28 & 1,79 & 287 & ,315 & ,753 \\
\hline & Erkek & 79 & 6,35 & 1,70 & & & \\
\hline
\end{tabular}


Tablo 5'te görüldüğü gibi, araştırmaya katılan öğretmen adaylarının bilgi uçurma tercihlerinde ve kültürel değerlerinde cinsiyet değişkenine göre anlamlı bir fark bulunmamaktadır.

4.5.Bilgi uçurma biçimi tercihinin ve kültürel değerlerin mezun olunan bölüme göre farklılaşma durumu
Katılımcıların bilgi uçurma tercihlerinin ve kültürel değerlerinin mezun olunan bölüme göre fark yaratıp yaratmadığına Kruskal Wallis testi ile bakılmıştır. Faklılı̆̆ın hangi gruplar arasında olduğunun belirlenmesi için Mann Whitney U-Testi yapılmıştır. Tablo 6'da analiz sonuçları yer almaktadır.

Tablo 6. Bilgi Uçurma Tercihi ve Kültürel Değerlerin Mezun Olunan Bölüme Göre Kruskal Wallis Testi Sonuçları

\begin{tabular}{|c|c|c|c|c|c|c|c|}
\hline & Bölüm & $\mathrm{n}$ & $\begin{array}{l}\text { Sira ortala- } \\
\text { mas1 }\end{array}$ & $\mathrm{Sd}$ & $x^{2}$ & $p$ & Fark \\
\hline \multirow{8}{*}{ İçe } & Dil & 124 & 152,96 & 7 & 6,96 & .432 & - \\
\hline & Sanat ve Tasarım & 77 & 140,92 & & & & \\
\hline & Felsefe & 12 & 154,79 & & & & \\
\hline & Sosyoloji & 5 & 86,20 & & & & \\
\hline & Tarih & 27 & 140,07 & & & & \\
\hline & Fizik & 20 & 138,73 & & & & \\
\hline & $\begin{array}{l}\text { Ziraat Mühendis- } \\
\text { liği }\end{array}$ & 6 & 95,58 & & & & \\
\hline & İlahiyat & 17 & 139,97 & & & & \\
\hline \multirow{8}{*}{ Dişa } & Dil & 124 & 129,65 & 7 & 15,340 & .032 & $1-3$ \\
\hline & Sanat ve Tasarım & 77 & 146,44 & & & & $1-5$ \\
\hline & Felsefe & 12 & 203,92 & & & & $1-6$ \\
\hline & Sosyoloji & 5 & 168,80 & & & & \\
\hline & Tarih & 27 & 169,20 & & & & \\
\hline & Fizik & 20 & 165,88 & & & & \\
\hline & $\begin{array}{l}\text { Ziraat Mühendis- } \\
\text { liği }\end{array}$ & 6 & 112,42 & & & & \\
\hline & İlahiyat & 17 & 141,91 & & & & \\
\hline \multirow{8}{*}{$\begin{array}{l}\text { Kimliğini açıklaya- } \\
\text { rak }\end{array}$} & Dil & 122 & 133,26 & 7 & 6,864 & .443 & - \\
\hline & Sanat ve Tasarım & 76 & 151,53 & & & & \\
\hline & Felsefe & 12 & 171,46 & & & & \\
\hline & Sosyoloji & 5 & 140,70 & & & & \\
\hline & Tarih & 27 & 152,43 & & & & \\
\hline & Fizik & 20 & 146,28 & & & & \\
\hline & $\begin{array}{l}\text { Ziraat Mühendis- } \\
\text { liği }\end{array}$ & 6 & 94,17 & & & & \\
\hline & İlahiyat & 17 & 153,76 & & & & \\
\hline \multirow{8}{*}{$\begin{array}{l}\text { Kimliğini saklaya- } \\
\text { rak }\end{array}$} & Dil & 124 & 150,31 & 7 & 9,031 & .250 & - \\
\hline & Sanat ve Tasarım & 77 & 130,94 & & & & \\
\hline & Felsefe & 12 & 120,13 & & & & \\
\hline & Sosyoloji & 5 & 182,30 & & & & \\
\hline & Tarih & 27 & 147,46 & & & & \\
\hline & Fizik & 20 & 164,53 & & & & \\
\hline & $\begin{array}{l}\text { Ziraat Mühendis- } \\
\text { liği }\end{array}$ & 6 & 192,17 & & & & \\
\hline & İlahiyat & 17 & 124,53 & & & & \\
\hline
\end{tabular}




\begin{tabular}{|c|c|c|c|c|c|c|c|}
\hline \multirow{8}{*}{ Resmi } & Dil & 124 & 146,92 & 7 & 3,743 & .809 & - \\
\hline & Sanat ve Tasarım & 77 & 141,51 & & & & \\
\hline & Felsefe & 12 & 133,83 & & & & \\
\hline & Sosyoloji & 5 & 126,00 & & & & \\
\hline & Tarih & 27 & 155,78 & & & & \\
\hline & Fizik & 20 & 137,58 & & & & \\
\hline & $\begin{array}{l}\text { Ziraat Mühendis- } \\
\text { liği }\end{array}$ & 6 & 99,58 & & & & \\
\hline & İlahiyat & 17 & 159,50 & & & & \\
\hline \multirow{8}{*}{ Resmi olmayan } & Dil & 124 & 148,63 & 7 & 6,134 & .524 & - \\
\hline & Sanat ve Tasarım & 77 & 142,77 & & & & \\
\hline & Felsefe & 12 & 196,42 & & & & \\
\hline & Sosyoloji & 5 & 136,50 & & & & \\
\hline & Tarih & 27 & 142,02 & & & & \\
\hline & Fizik & 20 & 128,83 & & & & \\
\hline & $\begin{array}{l}\text { Ziraat Mühendis- } \\
\text { liği }\end{array}$ & 6 & 186,83 & & & & \\
\hline & İlahiyat & 17 & 114,41 & & & & \\
\hline \multirow{8}{*}{ Bireyci } & Dil & 124 & 150,13 & 7 & 10,80 & .143 & - \\
\hline & Sanat ve Tasarım & 77 & 151,38 & & & & \\
\hline & Felsefe & 12 & 113,50 & & & & \\
\hline & Sosyoloji & 5 & 86,40 & & & & \\
\hline & Tarih & 27 & 153,59 & & & & \\
\hline & Fizik & 20 & 103,63 & & & & \\
\hline & $\begin{array}{l}\text { Ziraat Mühendis- } \\
\text { liği }\end{array}$ & 6 & 129,83 & & & & \\
\hline & İlahiyat & 17 & 139,21 & & & & \\
\hline \multirow{8}{*}{ Toplulukçu } & Dil & 124 & 141,91 & 7 & 11,192 & .130 & - \\
\hline & Sanat ve Tasarım & 77 & 136,32 & & & & \\
\hline & Felsefe & 12 & 135,08 & & & & \\
\hline & Sosyoloji & 5 & 62,10 & & & & \\
\hline & Tarih & 27 & 168,57 & & & & \\
\hline & Fizik & 20 & 170,83 & & & & \\
\hline & $\begin{array}{l}\text { Ziraat Mühendis- } \\
\text { liği }\end{array}$ & 6 & 167,42 & & & & \\
\hline & İlahiyat & 17 & 154,00 & & & & \\
\hline
\end{tabular}

Tablo 6'ya göre; katılımcıların dışa bilgi uçurma tercihleri mezun olunan bölüme göre anlamlı bir şekilde farklılaşmaktadır [ $\chi 22=15,340$, $\mathrm{p}<$.05]. Farklılığın hangi gruplar arasında olduğunun belirlenmesi için Mann Whitney U-Testi yapılmıştır. Buna göre, dil bölümünden mezun olan katılımcilar ile felsefe ( $U=368,000, p<.05)$, tarih $(\mathrm{U}=1199,500, \mathrm{p}<.05)$ ve fizik $(\mathrm{U}=893,500$, $\mathrm{p}<.05)$, bölümlerinden mezun olanlar arasında anlamlı bir fark vardır. Sıra ortalamaları dikkate alındığında, en yüksek ortalamaya felsefe mezunlarının, en düşük ortalamaya ise ilahiyat mezunlarının sahip oldukları görülmektedir.

\section{6. Öğretmen adaylarının olası bilgi uçurma tercihlerinde kültürel değerlerine göre farkl1- laşma durumu}

Öğretmen adaylarının olası bilgi uçurma tercihleriyle kültürel değerleri arasındaki ilişkiyi ortaya koymak için Pearson korelasyon analizi yapılmıştır. Analiz sonuçları Tablo 7'de yer almaktadir. 
Tablo 7. Pearson Momentler Çarpımı Korelasyon Katsayısı Testi Sonuçları

\begin{tabular}{|c|c|c|c|c|c|c|c|c|}
\hline & İçe & Dişa & $\begin{array}{l}\text { Kimliğini } \\
\text { açıklayarak }\end{array}$ & Anonim & Resmi & $\begin{array}{l}\text { Resmi } \\
\text { olmayan }\end{array}$ & Bireyci & Toplulukçu \\
\hline \multicolumn{9}{|l|}{ İçe } \\
\hline Dişa & $.391^{*}$ & & & & & & & \\
\hline $\begin{array}{l}\text { Kimliğini } \\
\text { açıklayarak }\end{array}$ & $.121^{*}$ & $.205^{*}$ & & & & & & \\
\hline $\begin{array}{l}\text { Kimliğini } \\
\text { saklayarak }\end{array}$ & $.108^{*}$ & .114 & $-.459^{*}$ & & & & & \\
\hline Resmi & $.243^{*}$ & $.221^{*}$ & $.218^{*}$ & .019 & & & & \\
\hline $\begin{array}{l}\text { Resmi } \\
\text { olmayan }\end{array}$ & $.250^{*}$ & $.348^{*}$ & .029 & $.272^{*}$ & $.170^{*}$ & & & \\
\hline Bireyci & $.147^{*}$ & $.135^{*}$ & $.196^{*}$ & -.086 & $.123^{*}$ & .077 & & \\
\hline Toplulukçu & $155^{*}$ & .109 & .079 & -.037 & -.037 & .076 & .108 & \\
\hline
\end{tabular}

Tablo 7'ya göre içe bilgi uçurma tercihi ile bireyci kültür değeri arasında pozitif ve anlamlı ilişki vardır ( $\mathrm{r}=.147, \mathrm{p}<0.1)$.Dışa bilgi uçurma tercihi ile bireyci kültür değeri arasında pozitif ve anlamlı ilişki vardır ( $\mathrm{r}=.135, \mathrm{p}<0.1)$.Kimliğini açılama tercihi ile bireyci kültür değeri arasında pozitif ve anlamlı ilişki vardır ( $\mathrm{r}=.196$, $\mathrm{p}<0.1)$.Resmi kanalı kullanma tercihi ile bireyci kültür düzeyi arasında pozitif ve anlamlı ilişki vardır $(\mathrm{r}=.123, \mathrm{p}<0.1)$. Son olarak içe bilgi uçurma tercihi ile toplulukçu kültür değeri arasında pozitif ve anlamlı ilişki vardır ( $\mathrm{r}=.155$, $\mathrm{p}<0.1)$.

\section{SONUÇ VE ÖNERILER}

$\mathrm{Bu}$ çalışma, öğretmen adaylarının olası bilgi uçurma tercihleri ile kültürel değerleri arasındaki ilişkiyi belirlemek amacı ile gerçekleştirilmiştir. Araştırma kapsamında cinsiyetin ve mezun olunan bölümün adayların olası bilgi uçurma tercihlerine ve kültürel değerlerine etkisinin olup olmadığına da bakılmıştır. Araştırma bir lisans programından mezun olmuş formasyon öğrencileri üzerine yapılmıştır.

Araştırmaya katılan öğretmen adaylarına öncelikle okullarda hangi etik dış olaylar ile karşılaştıklarında, bu durumu düzeltmek veya ortadan kaldırmak için bir yerlere bilgi vermeyi düşünecekleri soruldu. Katılımcılar öncelikle, kime yapılırsa yapılsın (öğrenci veya diğer işgörenler) cinsel tacizin mutlaka bir yerlere bildirilmesi gerektiğini düşündüklerini belirtmişlerdir. Cinsel tacizi, rüşvet ve okulun ödeneğinden paranın çalınması takip etmektedir. Diğer yandan, okula ait pahalı bir eşyanın çalınması bir yerlere bilgi uçurmada öncelikli iken, okulun basit bir aletinin çalınması en az haber verilmesi gereken bir durum olarak göze çarpmaktadır. Araştırmanın bulguları hem Toker-Gökçe ve Oğuz'un (2014) hem de TokerGökçe ve Alataş'ın (2014) bulguları ile tutarlılık göstermektedir. Ayrıca Toker Gökçe'nin (2013a) bilgi uçuran öğretmenleri irdelediği araştırmada sözü edilen eylemleri rapor ettiği belirlenmiştir. Dolayısı ile araştırmanın bulguları alanyazın ile tutarlıdır. Bu sonuçlar cinsel tacizin ve hırsızlığın eğitimciler tarafından kabul edilemez olduğunu göstermesi bakımından önemlidir. Bundan sonra yapılacak nitel çalışmaların eğitimcilerin ne tür eylemlerin kabul edilemez olduğunu belirlemede daha ayrıntılı bilgi vereceği düşünülmektedir. Dolayısı ile okullarda gerçekleşen etik, yasa dışı eylemleri tanıması bakımından bilgi uçurmaya yönelik nitel çalışmaların yapılması önerilmektedir.

Araştırma sonucuna göre öğretmen adayları okulun içindeki işgörenlerden ziyade MEB 
veya veliler gibi okulun dişındaki birilerine bildirmeyi tercih edeceklerini düşünmektedir. Toker Gökçe'nin (2013a) araştırmasına göre öğretmenler hem dışa hem de içe bilgi uçurmaktadır. Toker-Gökçe ve Oğuz'un (2014) araştırmasına göre öğretmenler dışa bilgi uçurmayı tercih edeceğini belirtirken, TokerGökçe ve Alataş'ın (2014) çalışmasında öğretmenler içe bilgi uçurmayı tercih edeceğini belirtiştir. Dolayısı ile araştırmanın bu bulgusu alanyazın ile kısmen tutarlıdır. Buna göre öğretmen adaylarının kendilerini kararlarında daha özgür hissettikleri, ancak nedense göreve başladıktan sonra gözledikleri sorunları örgüt içinde çözme yolunu tercih ettikleri sonucu çıkmaktadır. Nitekim Toker Gökçe'nin (2013c) öğretmenlerin örgüte bağlllığı ile bilgi uçurma tercihi arasındaki ilişkiyi inceleyen çalışmasında öğretmenlerin yarıya yakını herhangi bir etik veya yasa dışı olaya tanık olduğunda bunu bir yere bildirmeyeceğini belirtmiştir. Söz konusu çalışmada katılımcıların diğer yarısı da tanık oldukları eylem hakkında içe bilgi uçurarak sorunu örgüt içinde çözmeyi tercih edeceğini belirtmiştir.

Araştırma sonucuna göre öğretmen adayları daha yüksek oranda resmi kanalları kullanmay1 tercih edeceklerini belirmektedir. Oysa Toker Gökçe'nin (2013a, 2013c) araştırma sonuçları bunun tam tersini ortaya koymuştur. Bununla birlikte araştırmanın bu bulgusu Toker-Gökçe ve Oğuz'un (2014) bulguları ile tutarlılık göstermektedir. Diğer yandan öğretmen adayları kimliğini açıklayarak bilgi uçuracaklarını belirtmiştir. Alan yazında eğitimcilerin her iki biçimde de bilgi uçurabileceğini göstermektedir. Dolayısı ile araştırmanın bu bulgusu da alan yazın ile benzerlik göstermektedir.

Araştırma sonucuna göre öğretmen adayları, toplulukçuluğa göre daha yüksek düzeyde bireyci kültürel değere sahip görünmektedir. Araştırmanın bu bulgusu Toker Gökçe'nin (2013b) bulgusu ile benzerlik gösterirken, Toker-Gökçe ve Oğuz'un (2014) bulgusu ile tutarlılık göstermemektedir. Araştırmanın bu bulgusu toplum ve eğitim sistemi değiştikçe kültürel değerlerin de değişebileceği düşüncesini destekler görünmektedir. Dolayısı ile eğitimcilerin kültürel değerlerini karşılaştırmalı olarak irdeleyen araştırmaların yapılması önerilmektedir.

Araştırma sonucuna göre öğretmen adaylarının cinsiyeti bilgi uçurma tercihinde bir fark yaratmamaktadır. Toker Gökçe'nin (2013b, 2013c) çalışmalarında erkek eğitimcilerin kadın eğitimcilerden daha yüksek düzeyde bilgi uçurduğu veya bilgi uçurmayı tercih ettiği belirlenmiştir. Bununla birlikte araştırmanın bu bulgusu Toker-Gökçe ve Oğuz'un (2014) bulgusu ile tutarlılık göstermektedir. Ayrıca araştırma sonucuna göre öğretmen adaylarının mezun oldukları bölüme göre bilgi uçurma tercihi farklılaşmaktadır. Araştırmanın bu bulgusuna yönelik alanyazına rastlanmamıştır.

Son olarak öğretmen adaylarının dışa bilgi uçurma tercihi ile bireyci kültür değeri arasında pozitif ve anlamlı ilişki bulunmuştur. Araştırma sonucuna göre bireyci kültürel değere sahip olma ile hem içe hem de dışa, resmi kanalları kullanarak ve kimliğini açıklayarak bilgi uçurma arasında pozitif yönde anlamlı bir ilişki vardır. Buna rağmen toplulukçu kültürel değer yalnızca içe bilgi uçurma ile pozitif yönde anlamlı bir ilişki göstermektedir. Nayir and Herzig (2012) bireycilik ile dışa ve anonim bilgi uçurma arasında pozitif yönde anlamlı bir ilişki bulmuştur. Toker Gökçe'nin (2013b) ise toplulukçuluk ile dişa ve anonim bilgi uçurma arasında pozitif yönde anlamlı bir ilişki bulurken, bireycilik ile yalnızca anonim bilgi uçurma arasında pozitif yönde anlamlı bir ilişki bulmuştur. Dolayısı ile araştırmanın bulguları alanyazın ile tutarlıdır. 
Bu çalışma öğretmen adaylarının sahip oldukları kültürel değerleri ve olası bilgi uçurma tercihlerini ortaya koyması bakımından alanyazına katkıda bulunmaktadır. Araştırmanın benzerinin nitel olarak yapılması alanyazına derinlemesine bilgi saylayacağından, önerilmektedir. Bu araştırma öğretmenlerin okullar- da karşılaştıkları etik veya yasa dışı eylemleri düzeltmede veya ortadan kaldırmada sorumlulukları olduğunu vurgulamaktadır. Araştırmanın bulgularının söz konusu etik veya yasa dişı olaylar karşısında ne yapılacağı yönünde eğitimcilere yol göstereceği düşünülmektedir.

\section{Kaynaklar}

Asian Institute of Management. (2006). Whistle blowing in the philippines: awareness, attitudes and structures. Contract No. 7137453. Hills Governance Center. www.aim-hills.ph. İndirme Tarihi: 27.04.2012.

Henle, C. A., Giacalone, R. A., and Jurkiewicz, C. L. (2005).The role of ethical ideology in workplace deviance. Journal of Business Ethics, 56(3), 219-230.

Hofstede,G. (1980). Culture's consequences: International differencesin work-related values. Beverly Hills, CA: Sage Publications

Hofstede, G. (1983). The cultural relativity of organizational practices and theories. Journal of International Business Studies, 14(2), 75-89.

Institute of Public Administration Australia. (n.d). Whistleblowing. http://www.ipaa.org.au/. Indirme Tarihi: 27.04.2012.

Kavak, Y., Aydın, A., ve Akbaba Altun, S. (2007). Öğretmen yetiştirme ve eğitim fakülteleri (1982-2007). Ankara: YÖK Yayını 2007-5.

Miceli, M. P., Near, J. P. (1985). Characteristics of organizational climate and perceived wrongdoing associated with whistleblowing decisions. Personnel Psychology, 38 (3), 525-544.

Miceli, M.P., Near, J.P. (1988). Individual and situatıonal correlates of whistle-blowing Personnel Psycho$\log y, 41,267-281$.

Miceli, M. P. Near, J. P., Schwenk, C. R. (1991). Who blows the whistle and why? Industrial and Labor Relations Review, 45 (1), 113-130.

Miceli, M. P., Near, J. P. (1994). Relationships among value congruence, perceived victimization, and retaliation against whistleblowers: the case of internal auditors'. J. Management, 20, 773-794.

Miceli, M. P., Near, J.P. (2005). Standing uporstanding by: What predicts blowing the whistle on organizational wrong doing? Research in Personneland Human Resources Management, 24, 95-136.

Near, J.P., Rehg, M.T., Scotter, J.R.V., Miceli, M.P. (2004). Does type of wrongdoing affect the whistleblowing process? Business Ethics Quarterly, 14( 2), 219-242.

Park, H., Blenkinsopp, J., Oktem, M. K., Omurgonulsen, U. (2008). Cultural orientation and attitudes toward different forms of whistleblowing: a comparison of south korea, turkey, and the u.k. Journal of Business Ethics, 82, 929-939.

Taras, V., Steel, P., Kirkman, B.L. (2012). Improving national cultural indices using a longitudinal metaanalysis of Hofstede's dimensions, Journal of World Business, 47, 329-341.

Toker Gökçe, A. (2013a). Okullarda bilgi uçurma: İş doyumu ve örgütsel bağlılık ilişkisi. Dicle Üniversitesi Ziya Gökalp Ĕ̆itim Fakültesi Dergisi, 22, 261-282.

Toker Gökçe A. (2013b). Teachers' value orientations as determinants of preference for external and anonymous whistleblowing. International Journal of Humanities and Social Science, 3(4), 163-173. 
Toker-Gökçe, A.,Oğuz, E. (11-13 Eylül 2014). Öğretmenlerin farklı bilgi uçurma tercihlerinde belirleyici olan kültürel değerleri. V. Ĕ̆itim Yönetimi Forumu Bildiri Özetleri Kitabı. EYFOR, Konya.

Toker-Gökçe, A. ve Alataş, H. (2014). (11-13 Eylül 2014). Öğretmenlerin istenmeyen yönetici davranışlarına yönelik tutumları: bilgi uçurma (whistle-blowing) mı? sessiz kalma mı? V. Eğitim Yönetimi Forumu Bildiri Özetleri Kitabı. EYFOR, Konya.

Vinten, G. (1996). Whistleblowing in the health-related professions. The Indian Journal of Medical Ethics.

Woiceshyn, J. (2011). A model for ethical decision making in business: reasoning, intuition, and rational moral principles. J Bus Ethics, 104, 311-323. 


\section{Extended Summary}

Whistle blowing means giving information about the organizational wrongdoings resulting in harm to third parties, and is an effective corporate governance mechanism against organizational wrongdoings (Miceli ve Near, 1985). Whistle-blowers can be a former or current employee of any organization. The organization might be for-profit or non-profit, private or public. An individual might blow the whistle in different ways. Park et al. (2008) proposed a typology of whistle blowing based on three dimensions. Each dimension represents individual's choice for whistle blowing formally or informally, internally, or externally, and identified or anonymously. Blowing the whistle formally, means reporting wrongdoing in an institutional form. There are different factors one of which is cultural values that effect individuals' decision to attempt whistle blowing. Therefore, researchers have examined the relationship between culture and whistle-blowing intentions comparing different cultures.

This paper examines whistle blowing intentions of prospective teachers. The study examined 1) the kinds of wrongdoings that the prospective teachers would blow the whistle when they observed; 2) modes of whistle blowing that that the prospective teachers would chose to report that case (internal, external, identified, anonymous, formal, informal); 3) the possible difference of whistle-blowing modes according to the participants' gender and study field; 4) the possible difference of whistle blowing modes according to the participants' cultural values; and 5) the possible relationship between the participants' cultural values and choices of whistle blowing.

The research was figured as survey model. The research group involved 289 prospective teachers who were participated a teacher certification program at İstanbul and Ankara in 2013-2014 academic year. 73\% ( $n=201)$ of the participants were female and $27 \%(n=79)$ were male. The instruments were constructed by the literature. Data analysis has included descriptive statistics, t-test, Kruskal Wallis H test, Mann Whitney U test, and Pearson correlation coefficient. The results revealed that the prospective teachers would blow the whistle when they would observe sexual abuse to the students $(\mathrm{f}=276)$, sexual abuse to the teachers and the other staff $(\mathrm{f}=274)$, bribery $(\mathrm{f}=266)$, and theft $(\mathrm{f}=264)$. The results are in line with the findings by Toker-Gökçe and Oğuz (2014). In addition, the prospective teachers would prefer external whistle blowing $(X=9.45)$ more than the internal mode $(X=8.46)$. Besides, they would prefer would prefer identified whistle blowing $(X=6.71)$ by using formal channels $(X=7.83)$. The prospective teachers have individualism cultural value $(X=8.21)$ more than the collectivism cultural value $(X=6.30)$. This result is in line with the findings by Toker Gökçe $(2013 \mathrm{~b})$ while it is not with the results by Toker-Gökçe and Oğuz (2014). There was not any significant difference between gender and the participants' cultural values. Similarly, there was not any significant difference between gender and the participants' choice of whistle blowing modes. This result is in line with the findings by Toker-Gökçe and Oğuz (2014). In addition, there was not any significant difference between graduation field and the participants' cultural values.

On the other hand, the external mode of whistle blowing choice was differentiated according to the graduation field. These results are in line with the findings by Toker-Gökçe and Oğuz (2014). Finally, there was positive significant relationship between the cultural value and the choice of whistle blowing. In detail, there was positive significant relationship between the individualism cultural value and the choice of internal mode of whistle blowing $(\mathrm{r}=.147, \mathrm{p}<0.1)$, and external mode of whistle blowing $(\mathrm{r}=.135, \mathrm{p}<0.1)$. In addition, there was positive significant relationship between the individualism cultural value and the choice of identified mode of whistle blowing $(\mathrm{r}=.196, \mathrm{p}<0.1)$, and formal mode of whistle blowing $(\mathrm{r}=.123, \mathrm{p}<0.1)$. Finally, there was positive significant relationship between the collectivism cultural value and the choice of internal mode of whistle blowing(r=.155, $\mathrm{p}<0.1)$. The fact that education at schools forms cultural value is well known. Therefore, it is possible that all reforms at the education system would differentiate prospective teachers' cultural values. Thus, the need of studying whistle blowing among the prospective teachers as well as the teachers is arisen. 